\title{
Demonstration of inducible TFPI-2 mRNA synthesis in BeWo and JEG-3 trophoblast cells using a competitive RT-PCR
}

\author{
Sophie Iochmann, Pascale Reverdiau-Moalic, Florent Hubé, Pierre Bardos, Yves Gruel* \\ Laboratoire d'Hématologie-Hémostase, EA 3249 “Cellules Hématopoïétiques, Hémostase et Greffe”, Faculté de Médecine, 2 bis Boulevard Tonnellé, \\ 37032 Tours Cedex, France
}

Received 4 August 2001; accepted 28 November 2001

Accepting Editor: J. Soria

\begin{abstract}
Tissue factor pathway inhibitor-2 (TFPI-2) displays structural similarities with TFPI-1, the major inhibitor of tissue factor (TF)/ factor VIIa. It is synthesized mostly by syncytiotrophoblast in the placenta, but its physiological functions are not fully understood. We studied the synthesis of TFPI-2 mRNA and that of TFPI-1 and TF in three human trophoblast cell lines, JAR, BeWo, and JEG-3. We first developed specific competitive reverse transcription-polymerase chain reaction (RT-PCR) assays for each gene studied using human umbilical vein endothelial cells (HUVEC). The three trophoblast cell lines strongly synthesized TF mRNA whereas the synthesis of TFPI-1 mRNA was very low. TFPI-2 mRNA was not detected in unstimulated or stimulated JAR cells. In contrast, JEG-3 and, to a lesser extent, BeWo produced significant amounts of TFPI-2 mRNA, which were significantly increased after stimulation with phorbol 12-myristate 13-acetate (PMA). However, tumor necrosis factor- $\alpha(\mathrm{TNF}-\alpha)$ had no effect on this synthesis. JEG-3 and BeWo are thus two cell lines that could be used to study TFPI-2 gene regulation and to investigate the role of TF, TFPI-1, and TFPI-2 during trophoblast differentiation. (C) 2002 Elsevier Science Ltd. All rights reserved.
\end{abstract}

Keywords: Tissue factor; TFPI-1; TFPI-2; Trophoblast cells; Competitive RT-PCR

\section{Introduction}

Tissue factor (TF) is a transmembrane cell surface receptor that specifically binds factors VII and VIIa and triggers blood coagulation. TF is abundant in placental extracts [1], but to date it has been mainly found within macrophages, endothelial cells, or fibroblast-like cells of connective tissues and not in trophoblast cells [2,3]. TF has also been detected in human microvilli membranes [4,5] that sheared off differentiated multinuclear syncytiotrophoblast

Abbreviations: GAPDH, glyceraldehyde-3-phosphate dehydrogenase; HUVEC, human umbilical vein endothelial cells; PP5, placental protein 5; PMA, phorbol 12-myristate 13-acetate; RT-PCR, reverse transcriptionpolymerase chain reaction; TF, tissue factor; TFPI, tissue factor pathway inhibitor; TNF- $\alpha$, tumor necrosis factor- $\alpha$

* Corresponding author. Tel.: +33-2-4747-4672; fax: +33-2-47475904.

E-mail addresses: iochmann@med.univ-tours.fr (S. Iochmann), gruel@med.univ-tours.fr (Y. Gruel). cells, which are themselves derived from the fusion of villous cytotrophoblast cells. Syncytiotrophoblast is in contact with maternal blood in the intervillous spaces and expresses von Willebrand factor and thrombomodulin $[6,7]$, supporting its role in maintaining the haemostatic balance of intervillous spaces, such as endothelial cells lining blood vessels $[8,9]$.

To regulate TF activity in blood vessels, endothelial cells constitutively express tissue factor pathway inhibitor, TFPI-1 [10], also synthesized by monocytes/macrophages [11-13], megakaryocytes [14], and smooth muscle cells [15]. Large amounts of TFPI-1 mRNA have also been detected in placental tissues by Northern blotting [16] but the protein was only localized in macrophages within the villi of term placenta [14]. TFPI-2, a second inhibitor of TF, also named placental protein 5 (PP5), was initially isolated from human placenta extracts [17] and plasma TFPI-2 levels increase during pregnancy [18]. TFPI-2 mRNA has also been detected by Northern blotting in the placenta [19] and more recently localized by in situ hybridization in the 
syncytiotrophoblast from the first trimester to term placenta while it was not detected in cytotrophoblast [20]. Protein was also detected in syncytiotrophoblast by previous immunohistological studies [21,22], but the role of TFPI-2 in the placenta is still not understood. Despite structural and sequence similarities to TFPI-1 [10,23], TFPI-2 weakly inhibits factor $\mathrm{Xa}$ and thrombin activities [23,24] and other functions are likely to be involved in the placenta, which is a particularly invasive and proliferative tissue.

Few techniques are available to isolate trophoblast cells to study TFPI-2 synthesis in normal placenta and they are all difficult and time-consuming. We therefore investigated whether a human continuous cell line could be used as a trophoblast cellular model to study TFPI-2 gene regulation. We first developed competitive and quantitative reverse transcription-polymerase chain reaction (RT-PCR) methods allowing evaluation of TFPI-2 mRNA synthesis in endothelial cells isolated from human umbilical vein (HUVEC) together with that of TF and TFPI-1, and we then applied this procedure to study three different trophoblast cell lines, JAR, BeWo, and JEG-3.

\section{Materials and methods}

\subsection{Cell isolation and culture}

Human trophoblast cell lines, JAR [25], BeWo [26], and JEG-3 [27], kindly provided by Dr. G. Chaouat, were grown to confluence in $25-\mathrm{cm}^{2}$ flasks (Greiner Labortechnik, Poitiers, France) at $37{ }^{\circ} \mathrm{C}$ in an atmosphere of $95 \%$ air and $5 \% \mathrm{CO}_{2}$. Cells were cultured in RPMI 1640 medium (Life Technologies, Cergy Pontoise, France) supplemented with $10 \%$ endotoxin-free heat-inactivated foetal calf serum (ATGC Biotechnologie, Noisy le Grand, France), $2 \mathrm{mM}$ L-glutamine, $1 \mathrm{mM}$ sodium pyruvate, $100 \mathrm{IU} / \mathrm{ml}$ penicillin, $100 \mu \mathrm{g} / \mathrm{ml}$ streptomycin, $25 \mathrm{mM}$ sodium bicarbonate for JAR cell culture or $15 \mathrm{mM}$ sodium bicarbonate and $2 \mathrm{mM}$ glucose for JEG-3 and BeWo cell cultures.

Endothelial cells were isolated from human umbilical cord veins as previously described [5] and grown to confluence at $37{ }^{\circ} \mathrm{C}$ in an atmosphere of $95 \%$ air and $5 \% \mathrm{CO}_{2}$ in $\mathrm{M}-199$ medium supplemented with $20 \%$ endotoxin-free heat-inacti- vated foetal calf serum, $2 \mathrm{mM}$ L-glutamine, $0.13 \%$ sodium bicarbonate, $25 \mathrm{mM}$ HEPES, $100 \mathrm{IU} / \mathrm{ml}$ penicillin, $100 \mu \mathrm{g} / \mathrm{ml}$ streptomycin, and $2.5 \mathrm{mg} / \mathrm{ml}$ fungizone. HUVEC were characterized by their typical morphology at confluence and their positive immunofluorescence using a polyclonal antibody specific for von Willebrand factor.

\subsection{Cell stimulation}

Confluent cells were washed with $\mathrm{Ca}^{2+}$ - and $\mathrm{Mg}^{2+}$-free Hanks' balanced salt solution and detached by $0.05 \%$ tryp$\sin -0.02 \%$ EDTA. Cell viability was determined by the Trypan blue dye exclusion test and ranged between $90 \%$ and $95 \%$. Endothelial cells at the first passage and trophoblast cells were then seeded in $1 \%$ gelatin-coated six-well plates (Falcon, Becton Dickinson, Le Pont de Claix, France) at $10^{6}$ cells per well and cultured for $18 \mathrm{~h}$ in complete medium. Trophoblast cells were then incubated with $20 \mathrm{ng} / \mathrm{ml}$ recombinant human tumor necrosis factor- $\alpha$ (TNF- $\alpha$, specific activity: $2 \times 10^{7} \mathrm{IU} / \mathrm{mg}$, Genzyme, Cambridge, MA, USA) for $90 \mathrm{~min}$ at $37{ }^{\circ} \mathrm{C}$ for JAR cells or $60 \mathrm{~min}$ for JEG-3 and BeWo cells. HUVEC were incubated with $10 \mathrm{ng} / \mathrm{ml}$ recombinant human TNF- $\alpha$ for $90 \mathrm{~min}$ at $37{ }^{\circ} \mathrm{C}$. Trophoblast and endothelial cells were also stimulated with $100 \mathrm{ng} / \mathrm{ml}$ phorbol 12-myristate 13-acetate (PMA, Sigma Aldrich Chimie, Saint Quentin Fallavier, France) for $4 \mathrm{~h}$ before mRNA extraction.

\subsection{Competitive RT-PCR}

Simultaneous TF, TFPI-1, and TFPI-2 mRNA expression was investigated using competitive RT-PCR assays. Heterologous DNA competitors were thus constructed for each gene studied using the PCR MIMIC kit (Clontech, Palo Alto, CA, USA) according to the manufacturer's instructions. Composite primers were designed to contain both the target-specific primer sequence and 20 nucleotides of the v-erbB sequence corresponding to the heterologous DNA fragment to be amplified. Initial PCR was carried out at $50{ }^{\circ} \mathrm{C}$ (annealing temperature) for 16 cycles with $2 \mathrm{ng}$ of heterologous DNA and $0.4 \mu \mathrm{M}$ of each composite primer. Second amplification of 23 cycles at $62{ }^{\circ} \mathrm{C}$ was performed with dilution of the first PCR and $0.4 \mu \mathrm{M}$ of each target-specific primer. The DNA competitors thus generated were then

Table 1

Primer sequences used in RT-PCR

\begin{tabular}{|c|c|c|c|c|}
\hline Transcript & Primer sequence $5^{\prime}-3^{\prime}$ & $\begin{array}{l}\text { Reference of } \\
\text { cDNA sequence }\end{array}$ & $\begin{array}{l}\text { Target PCR } \\
\text { product (bp) }\end{array}$ & $\begin{array}{l}\text { Competitor PCR } \\
\text { product (bp) }\end{array}$ \\
\hline \multirow[t]{2}{*}{$\mathrm{TF}$} & For CTACTGTTTCAGTGTTCAAGCAGTGA & {$[33]$} & 282 & 428 \\
\hline & Rev CAGTGCAATATAGCATTTGCAGTAGC & & & \\
\hline \multirow[t]{2}{*}{ TFPI-1 } & For GGAAGAAGATCCTGGAATATGTCGAGG & {$[31]$} & 230 & 378 \\
\hline & Rev CTTGGTTGATTGCGGAGTCAGGGAG & & & \\
\hline \multirow[t]{2}{*}{ TFPI-2 } & For CAGATGAAGCTACTTGTATGGGCTTC & {$[23]$} & 253 & 398 \\
\hline & Rev GGCAAAGCGAAGCTTTGGCATC & & & \\
\hline \multirow[t]{2}{*}{ GAPDH } & For ACAGTCCATGCCATCACTGCC & {$[28]$} & 265 & - \\
\hline & Rev GCCTGCТTCАСCАССАССТТСТTG & & & \\
\hline
\end{tabular}

For: forward; Rev: reverse. 
purified with Chroma Spin columns (Clontech) and quantified at $260 \mathrm{~nm}$ on a spectrophotometer or by comparing the electrophoretic band intensities of the target with those of known amounts of size markers ( $\phi$ X 174 DNA digested with HaeIII, Life Technologies) using the Multi Analyst/Macintosh software (Bio Rad, Ivry sur Seine, France). Competitors for TF, TFPI-1, and TFPI-2 yielded PCR products $150 \mathrm{bp}$ larger than the target sequence in order to be easily distinguished after gel electrophoresis (Table 1).

Total mRNA was isolated from $10^{6}$ cells of each trophoblast cell line or from $10^{6}$ HUVEC, stimulated with TNF- $\alpha$, PMA, or unstimulated, using the Dynabeads mRNA Direct kit (Dynal France, Compiègne, France) according to the manufacturer's instructions. Total mRNA (200 ng for $10^{6}$ cells) was then reverse-transcribed for $1 \mathrm{~h}$ at $42{ }^{\circ} \mathrm{C}$ in $1 \times$ incubation buffer containing $250 \mu \mathrm{M}$ of each deoxynucleoside triphosphate, $5 \mu \mathrm{M}$ oligo $(\mathrm{dT})_{20}, 25 \mathrm{U}$ of RNase inhibitor, and $20 \mathrm{U}$ of AMV Reverse Transcriptase (Roche Diagnostics, Meylan, France).

Competitive PCR were performed on samples containing a constant volume of first-strand cDNA $(0.8-3.2 \mu \mathrm{l}$ when mRNA expression was very low) and $2 \mu \mathrm{l}$ of twofold competitor dilutions. PCR was carried out in $1 \times$ Taq buffer (ATGC Biotechnologie) containing $200 \mu \mathrm{M}$ of each deoxynucleotide triphosphate, $0.4 \mu \mathrm{M}$ of each reverse- and forward-synthesized oligonucleotide primer (Genset, Paris, France) specific for human TF, TFPI-1, TFPI-2, or human glyceraldehyde-3-phosphate dehydrogenase (GAPDH) cDNA sequences (Table 1) and $0.5 \mathrm{U}$ of Super Taq DNA polymerase (ATGC Biotechnologie). Primers specific for TF and TFPI- 1 mRNA have been previously described $[29,30]$. The primers used for detection of TFPI-2 mRNA were defined taking into account the similarities between TFPI-1 and TFPI- 2 to avoid hybridization to homologous sequences $[23,31]$. In addition, all primers were designed to have melting temperatures in the same range, allowing simultaneous amplification, and to span one intron to distinguish genomic DNA from cDNA amplifications. PCR was set up in the GeneAmp PCR system 2400 (Applied Biosystems, Courtaboeuf, France) programmed for an initial denaturation step of $3 \mathrm{~min}$ at $95{ }^{\circ} \mathrm{C}$, followed by 35 cycles at $95{ }^{\circ} \mathrm{C}$ for $30 \mathrm{~s}, 62{ }^{\circ} \mathrm{C}$ for $30 \mathrm{~s}$, and $72{ }^{\circ} \mathrm{C}$ for $30 \mathrm{~s}$, and the final extension step was performed at $72{ }^{\circ} \mathrm{C}$ for $7 \mathrm{~min}$.

PCR products were then analyzed by electrophoresis through $1.6 \%$ agarose gel in TBE buffer $(90 \mathrm{mM}$ Tris $-\mathrm{HCl}$, $90 \mathrm{mM}$ borate acid, $2.5 \mathrm{mM}$ EDTA) containing $1 \mu \mathrm{g} / \mathrm{ml}$ ethidium bromide and visualized by UV transillumination (Gel Doc 1000 system, Bio Rad). Band intensities of PCR products were measured by the Multi Analyst/Macintosh software and expressed in arbitrary units corresponding to pixel integration after correction taking into account the size difference between competitor and target cDNA. The logarithm ratio of target to competitor band intensities was plotted as a function of the logarithm of the competitor amount added. The amount of target cDNA was determined when the logarithm of the ratio was equal to zero and was expressed in attomoles for $5 \times 10^{4}$ cells.

In order to ensure that target and competitor cDNA have similar amplification efficiency, equal amounts were coamplified for 29-44 cycles and the intensity values of PCR

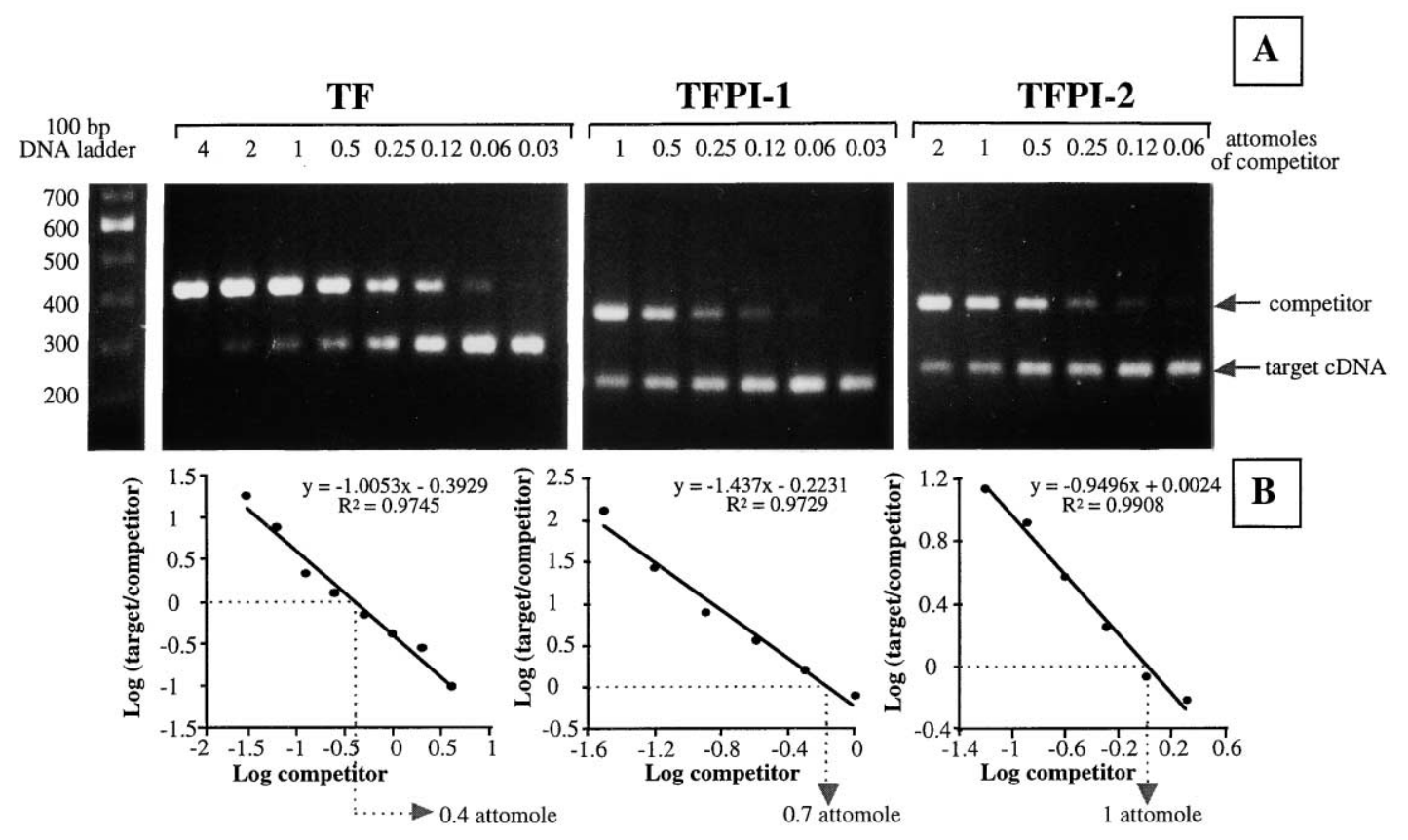

Fig. 1. Competitive RT-PCR assay specific for TF, TFPI-1, and TFPI-2 in HUVEC. (A) Twofold dilutions of competitor were coamplified with constant aliquots of cDNA from $2 \times 10^{4}$ HUVEC stimulated with PMA. (B) The logarithm ratio of target to competitor band intensities was plotted as a function of the logarithm of the amount of competitor added. The amount of target cDNA was calculated with the linear regression curve. 
products were then plotted as a function of the cycle numbers. For each gene studied, regression lines with comparable slopes were obtained for competitor and target.

RT-PCR products specific for TF, TFPI-1, and TFPI-2 were automatically sequenced using the dideoxynucleotide chain termination method [32] on a Perkin Elmer Abi Perkin 377 automat (INSERM U316, Tours, France). Sequencing was performed on both strands with the reverse and forward primers specific for TF, TFPI-1, and TFPI-2 used for RT-PCR.

\section{Results}

\subsection{Development of competitive RT-PCR methods}

Competitive RT-PCR assays were developed using HUVEC in which we quantified TF, TFPI-1, and TFPI-2 mRNA expression after stimulation by PMA (Fig. 1). Serial dilutions of competitors, starting from amounts of 4,1 , and 2 amol of TF, TFPI-1, and TFPI-2 cDNA competitor, respectively, were coamplified with a constant volume of $0.8 \mu \mathrm{l}$ first-strand cDNA obtained from PMA-treated HUVEC. For every gene studied, an increase in target PCR products was observed when competitor PCR products decreased (Fig. 1A). Thus, when the intensities of target and competitor PCR products were equal, we could evaluate the amount of target cDNA present in the sample tested. After measuring target and competitor PCR product intensities, the logarithm of their ratio was plotted as a function of the logarithm of the amount of competitor present in the mixture reaction (Fig. 1B). Target cDNA levels were then calculated using the regression curves obtained, which were all linear with correlation coefficients higher than 0.9. Using the above experimental conditions, the amounts of TF, TFPI-1, and TFPI- 2 cDNA measured from $2 \times 10^{4}$ HUVEC and stimulated with PMA were 0.4, 0.7, and 1 amol, respectively (Fig. 1B).

\subsection{Quantification of TF, TFPI-1, TFPI-2 mRNA expression in trophoblast cell lines}

TF, TFPI-1, and TFPI-2 mRNA expression was then studied in JAR, BeWo, and JEG-3 trophoblast cells. The optimal TNF- $\alpha$ and PMA concentrations and incubation times to be used for cell stimulation were first defined, corresponding to $90 \mathrm{~min}$ for JAR and $60 \mathrm{~min}$ for BeWo and JEG-3 in the presence of $20 \mathrm{ng} / \mathrm{ml} \mathrm{TNF-} \alpha$ and $4 \mathrm{~h}$ with $100 \mathrm{ng} / \mathrm{ml}$ of PMA.

Total mRNA was isolated from $10^{6}$ cells and RT-PCR specific for TF, TFPI-1, TFPI-2, and GAPDH was then simultaneously performed using single-strand cDNA from about $5 \times 10^{4}$ cells. RT-PCR products were obtained as single bands of 282, 230, 253, and $265 \mathrm{bp}$, the expected sizes of TF, TFPI-1, TFPI-2, and GAPDH cDNA, respectively. The sequencing of RT-PCR products was similar to the previously published sequences [23,31,33] and confirmed the specificity of the technique. Cell expression of

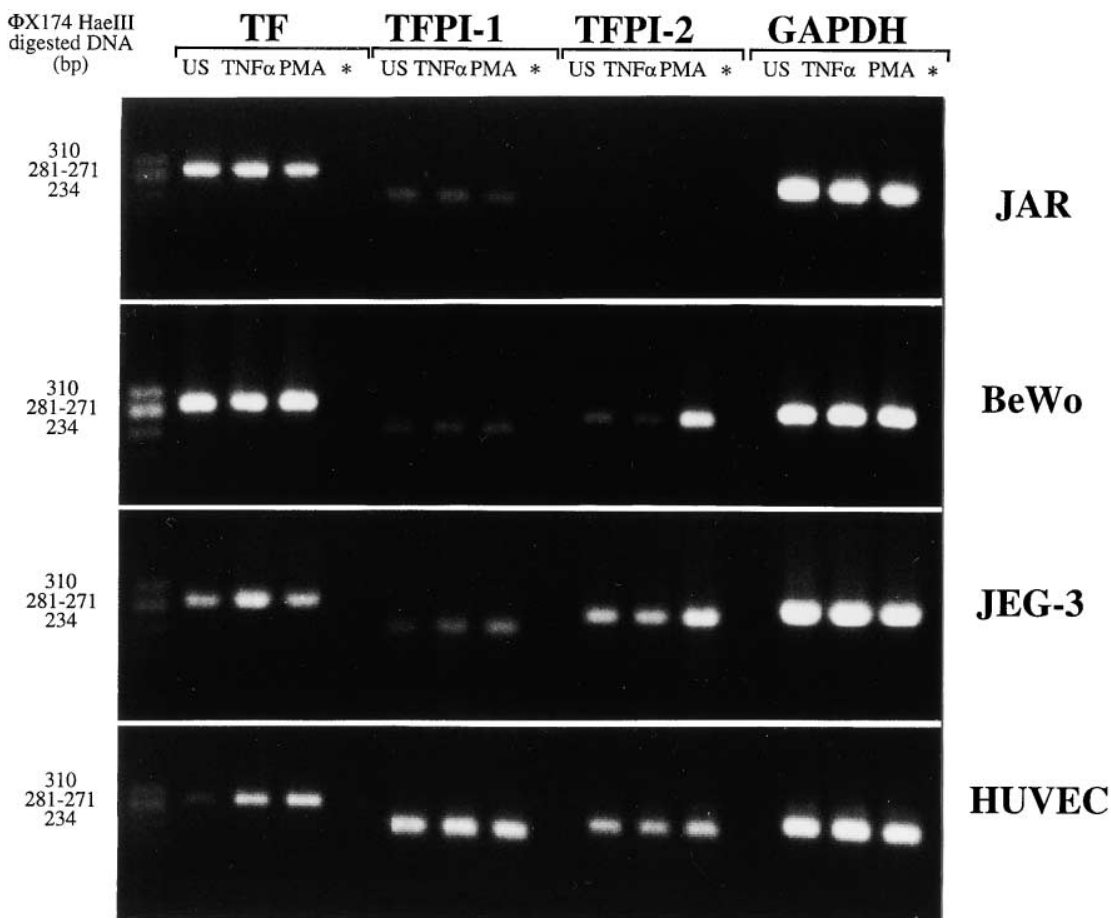

Fig. 2. Detection of TF, TFPI-1, TFPI-2, and GAPDH mRNA in JAR, BeWo, and JEG-3 trophoblast cell lines. Trophoblast cells were unstimulated (US) or incubated with $20 \mathrm{ng} / \mathrm{ml} \mathrm{TNF- \alpha}$ or $100 \mathrm{ng} / \mathrm{ml} \mathrm{PMA}$. Endothelial cells used as control cells were unstimulated or treated with $10 \mathrm{ng} / \mathrm{ml} \mathrm{TNF}-\alpha$ or $100 \mathrm{ng} / \mathrm{ml}$ PMA. 

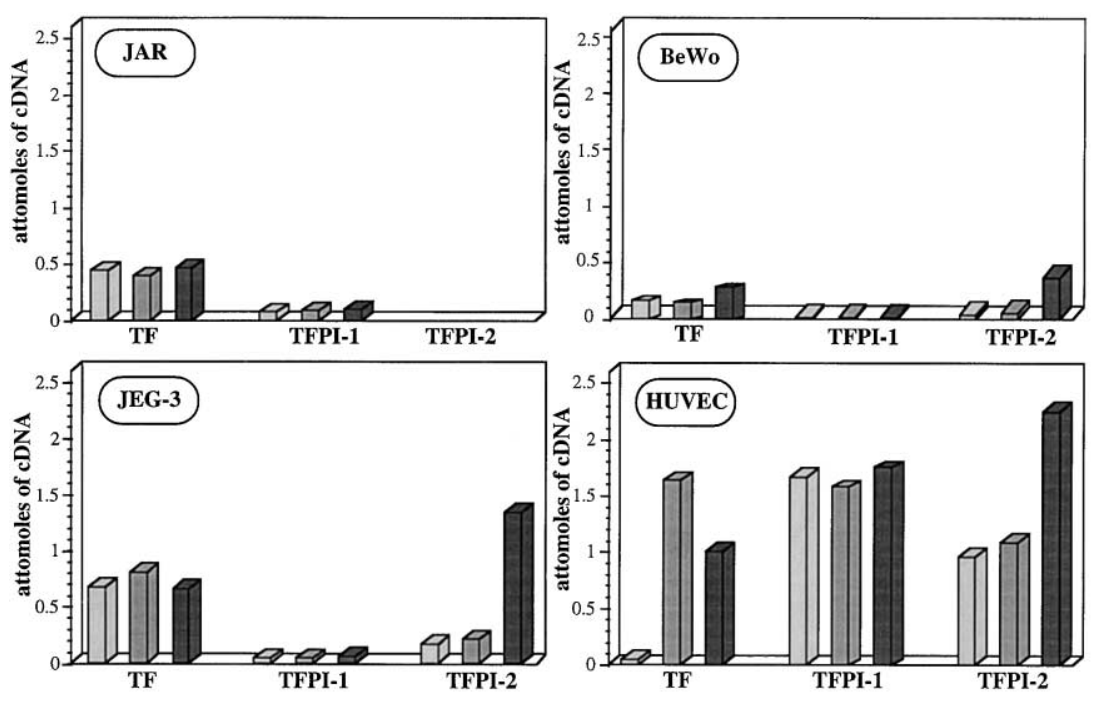

Fig. 3. Quantification of TF, TFPI-1, and TFPI-2 cDNA from JAR, BeWo, JEG-3 trophoblast cell lines and from HUVEC. Results are expressed in attomoles of cDNA obtained from $5 \times 10^{4}$ cells, unstimulated $(\square)$, incubated with TNF- $\alpha$ (棝) at $20 \mathrm{ng} / \mathrm{ml}$ for trophoblast cells or $10 \mathrm{ng} / \mathrm{ml}$ for endothelial cells, or incubated with $100 \mathrm{ng} / \mathrm{ml}$ PMA (ם). These data are representative of three independent experiments.

GAPDH, used as control, was not affected in any experiment, regardless of cell stimulation (Fig. 2).

Significant amounts of TF mRNA were detected in all trophoblast cells with and without inducer (Fig. 2). In contrast, very low levels of TFPI- 1 mRNA were present in all unstimulated trophoblast cells, particularly in JAR and BeWo, and appeared unmodified after incubation with TNF- $\alpha$ or PMA. TFPI-2 mRNA expression was not detected in JAR even after incubation with TNF- $\alpha$ or PMA. In contrast, significant synthesis was detected in unstimulated JEG-3 and BeWo, slightly higher in the former. After stimulation for $4 \mathrm{~h}$ with PMA, TFPI- 2 mRNA synthesis was clearly increased in these two trophoblast cell lines.

To quantify these results, competitive RT-PCR specific for TF, TFPI-1, and TFPI-2 was then performed, and results obtained from $5 \times 10^{4}$ cells and with twofold dilution of competitor were expressed in attomoles of cDNA (Fig. 3). The three trophoblast cells constitutively expressed strong levels of TF mRNA, with about $0.4,0.18$, and 0.65 amol of TF cDNA from JAR, BeWo, and JEG-3, respectively, and TNF- $\alpha$ or PMA did not significantly modify this synthesis. In contrast, unstimulated HUVEC expressed a very low level of TF cDNA ( 0.05 amol) and a 32- or 20-fold increase in this amount was obtained when cells were stimulated with TNF- $\alpha$ or PMA, respectively. TFPI-1 cDNA level was lower than 0.1 amol in both unstimulated and stimulated trophoblast cells, in contrast to those measured with unstimulated HUVEC (1.6 amol) that remained unmodified when endothelial cells were treated with TNF- $\alpha$ or PMA. TFPI-2 mRNA was never detected in JAR cells whereas 0.03 and 0.17 amol of TFPI- 2 cDNA were quantified in unstimulated BeWo and JEG-3 cells, respectively. No significant effect of TNF- $\alpha$ on TFPI-2 mRNA synthesis was observed for either cell line. In contrast, TFPI-2 cDNA levels rose dramatically when cells were stimulated with
PMA, reaching a value of 0.36 amol for BeWo, corresponding to a 10.8 -fold increase in synthesis, and $1.3 \mathrm{amol}$ for JEG-3, corresponding to a 7.8-fold increment. By comparison, unstimulated HUVEC expressed 0.9 amol of TFPI-2 cDNA and a 2.6-fold increase in synthesis was measured when cells were incubated with PMA.

\section{Discussion}

TFPI-2, a 32-kDa Kunitz-type serine proteinase inhibitor, is particularly abundant in the placenta $[17,18,20]$, but its physiological role during pregnancy remains unknown. Apart from endothelial cells [34,35] and monocytes/macrophages [13], trophoblast cells are another potential source of TFPI-2 in the placenta. However, trophoblast cells are difficult to isolate from the normal placenta and this explains why continuous lines were previously employed to study expression of cytokine and hormone related to differentiation and invasion [36-38]. We therefore studied TFPI-2 mRNA synthesis in three different trophoblast cell lines (JAR, BeWo, and JEG-3) using specific competitive RT-PCR techniques adapted from a previously developed method that allowed the simultaneous detection of TF and TFPI- 1 mRNA on a limited number of cells [30]. To detect TFPI-2 mRNA, primers were designed taking into account the similarities between TFPI-1 and TFPI-2 cDNA sequences existing particularly in the regions coding the three tandem Kunitz-type protease inhibitor domains, K1, K2, and $\mathrm{K} 3$ [23,31]. We therefore chose a TFPI-2 reverse primer hybridizing the region located after the $\mathrm{K} 3$ domain and a forward primer corresponding to the end of the $\mathrm{K} 2$ domain.

We showed that two of the three trophoblast cell lines studied (i.e., BeWo and JEG-3) produced significant 
amounts of TFPI-2 mRNA, particularly when stimulated with PMA. In contrast, no synthesis of TFPI-2 mRNA could be detected in either unstimulated or stimulated JAR cells. In order to quantify TFPI-2 gene expression together with the expression of TF and TFPI-1, we developed competitive RT-PCR assays in HUVEC able to synthesize these three molecules. We prepared nonhomologous DNA competitors for each gene studied that were then coamplified with the target cDNA. Although DNA competitors do not allow checking of the reverse transcription step, they are more stable than RNA competitors and are thus frequently chosen for competitive RT-PCR [39-41]. Using such a competitive RT-PCR approach, we showed that PMA, previously identified to stimulate TFPI-2 expression in HUVEC $[34,35,42]$ and in fibroblast cells $[43,44]$, also increased TFPI-2 mRNA synthesis in trophoblast cells (i.e., 7.8- and 10.8-fold in JEG-3 and BeWo, respectively). In contrast, no significant effect of TNF- $\alpha$ on TFPI-2 mRNA synthesis by HUVEC was shown in our conditions. In a previous work, TFPI-2 mRNA synthesis was not detected by Northern blotting in JAR and BeWo whether cells were stimulated or not [20]. Our results observed with BeWo cells are therefore supporting by the higher sensitivity of RT-PCR to detect TFPI-2 mRNA compared to Northern blotting $[29,40]$.

$\mathrm{TF}$ is also produced in large amounts in the placenta, particularly in term syncytiotrophoblast microvilli [4,5]. In agreement with previous findings [5], we showed that TF mRNA was constitutively synthesized in the three cell lines studied, but these results could also be due to the tumoral origin of trophoblast cell lines [45-47]. To regulate procoagulant $\mathrm{TF}$ activity, normal endothelial cells expressed TFPI-1 but in the placenta this protein is not significantly produced by trophoblast cells and is only detected within macrophages of the placental villi [14]. Similarly and as shown by RT-PCR, TFPI-1 mRNA was also poorly synthesized in JAR, BeWo, and JEG-3 cells.

In contrast, TFPI-2 is produced in BeWo and JEG-3 at a significant level as well as in normal placenta. The physiological role of this proteinase inhibitor is unknown, but it could be involved in trophoblast invasion. Indeed, TFPI-2 down-regulates the activation of metalloproteinases by inhibiting plasmin and trypsin and also inhibits matrix degradation and invasion by tumoral cells $[43,44,48-51]$. These properties of TFPI-2 might thus be of importance in the placenta to regulate trophoblast invasion that involves metalloproteinases $[52,53]$. TFPI-2 might also participate in cell differentiation, leading to the formation of a multinucleated syncytiotrophoblast that is the main source of TFPI-2 in the normal human placenta $[20,21]$.

However, additional studies will be necessary to establish whether or not TFPI-2 is functionally important to regulate invasion and differentiation of trophoblast cells. JEG-3 and BeWo cells should be useful for such studies and also allow to study TFPI-2 gene regulation.

\section{Acknowledgments}

We particularly thank S. Marouillat and Dr. C. Andrès (INSERM U316, Laboratoire de Biochimie et de Biologie Moléculaire, Tours, France) for nucleotide sequencing, E. Rideau for excellent technical assistance, and D. Raine for editing the English language. This study was supported by the Conseil Régional du Centre.

\section{References}

[1] Freyssinet JM, Brami B, Gauchy J, Cazenave JP. Coextraction of thrombomodulin and tissue factor from human placenta: effects of concanavalin A and phospholipid environment on activity. Thromb Haemostasis 1986;55:112-8.

[2] Faulk WP, Labarrere CA, Carson SD. Tissue factor: identification and characterization of cell types in human placenta. Blood 1990;76:86-96.

[3] Fleck RA, Rao LVM, Rapaport SI, Varki N. Localization of human tissue factor antigen by immunostaining with monospecific, polyclonal anti-human tissue factor antibody. Thromb Res 1990;59:421-37.

[4] Carson SD, Perry GA, Pirruccello SJ. Fibroblast tissue factor: calcium and ionophore induce shape changes, release of membrane vesicles, and redistribution of tissue factor antigen in addition to increased procoagulant activity. Blood 1985;84:526-34.

[5] Reverdiau P, Jarousseau AC, Thibault G, Khalfoun B, Watier H, Lebranchu Y, Bardos P, Gruel Y. Tissue factor activity of syncytiotrophoblast plasma membranes and tumoral trophoblast cells in culture. Thromb Haemostasis 1995;73:49-54.

[6] Maruyama I, Bell CE, Majerus PW. Thrombomodulin is found on endothelium of arteries, veins, capillaries, and lymphatics, and on syncytiotrophoblast of human placenta. J Cell Biol 1985;101:363-71.

[7] Fazel A, Vincenot A, Malassine A, Soncin F, Gaussem P, Alsat E, EvainBrion D. Increase in expression and activity of thrombomodulin in term human syncytiotrophoblast microvilli. Placenta 1998;19: $261-8$.

[8] Yeh IT, Kurman RJ. Functional and morphologic expressions of trophoblast. Lab Invest 1989;61:1-3.

[9] Graham CH, Lala PK. Mechanisms of placental invasion of the uterus and their control. Biochem Cell Biol 1992;70:867-74.

[10] Sandset PM. Tissue factor pathway inhibitor (TFPI) - an update. Haemostasis 1996;26:154-65.

[11] McGee MP, Foster S, Wang X. Simultaneous expression of tissue factor and tissue factor pathway inhibitor by human monocytes. A potential mechanism for localized control of blood coagulation. J Exp Med 1994;179:1847-54.

[12] Petit L, Lesnik P, Dachet C, Moreau M, Chapman MJ. Tissue factor pathway inhibitor is expressed by human monocyte-derived macrophages - relationship to tissue factor induction by cholesterol and oxidized LDL. Arterioscler Thromb Vasc Biol 1999;19:309-15.

[13] Reverdiau-Moalic P, Iochmann S, Rideau E, Thibault G, Bardos P, Gruel Y. Expression of tissue pathway inhibitor 2 (TFPI-2) with tissue factor and TFPI-1 mRNA in blood monocyte-derived macrophages. Thromb Haemostasis 1999;SV:516.

[14] Werling RW, Zacharski LR, Kisiel W, Bajaj SP, Memoli VA, Rousseau SM. Distribution of tissue factor pathway inhibitor in normal and malignant human tissues. Thromb Haemostasis 1993;69:366-9.

[15] Caplice NM, Mueske CS, Kleppe LS, Simari RD. Presence of tissue factor pathway inhibitor in human atherosclerotic plaques is associated with reduced tissue factor activity. Circulation 1998;98:1051-7.

[16] Bajaj MS, Kuppuswamy MN, Manepalli AN, Bajaj SP. Transcriptional expression of tissue factor pathway inhibitor, thrombomodulin and von Willebrand factor in normal human tissues. Thromb Haemostasis 1999;82:1047-52. 
[17] Bützow R, Huhtala ML, Bohn H, Virtanen I, Seppälä M. Purification and characterization of placental protein 5. Biochem Biophys Res Commun 1988;150:483-90.

[18] Seppälä M, Rutanen E-M, Siiteri JE, Wahlström T, Koistinen R, Pietilä $\mathrm{R}$, Bohn $\mathrm{H}$. Immunologic and biological properties and clinical significance of placental proteins PP5 and PP12. Ann NY Acad Sci 1983;368-82.

[19] Miyagi Y, Koshikawa N, Yasumitsu H, Mizushima H, Miyagi E, Hirahara F, Aoki I, Misugi K, Umeda M, Miyazaki K. cDNA cloning and mRNA expression of a serine proteinase inhibitor secreted by cancer cells: identification as placental protein 5 and tissue factor pathway inhibitor-2. J Biochem 1994;116:939-42.

[20] Udagawa K, Miyagi Y, Hirahara F, Miyagi E, Nagashima Y, Minaguchi H, Misugi K, Yasumitsu H, Miyazaki K. Specific expression of PP5/TFPI-2 mRNA by syncytiotrophoblasts in human placenta as revealed by in situ hybridization. Placenta 1998;19: $217-23$.

[21] Seppälä M, Wahhlström T, Bohn H. Circulating levels and tissue localization of placental protein five (PP5) in pregnancy and trophoblastic disease: absence of PP5 expression in the malignant trophoblast. Int J Cancer 1979;24:6-10.

[22] Bützow R, Virtanen I, Seppälä M, Närvänen O, Stenman U-H, Ristimäki A, Bohn H. Monoclonal antibodies reacting with placental protein 5: use in radioimmunoassay, Western blot analysis, and immunohistochemistry. J Lab Clin Med 1988;111:249-56.

[23] Sprecher C. Molecular cloning, expression, and partial characterization of a second human TFPI. Proc Natl Acad Sci USA 1994;91: $3353-5$.

[24] Petersen LC, Sprecher CA, Foster DC, Blumberg H, Hamamoto T, Kisiel W. Inhibitory properties of a novel human Kunitz-type protease inhibitor homologous to tissue factor pathway inhibitor. Biochemistry 1996;35:266-72.

[25] Patillo RA, Ruckert A, Hussa R, Berstein R, Deles E. The JAR cell line, continuous human multihormone production and controls. In Vitro 1971;6:398-9.

[26] Patillo RA, Gey GO. The establishment of a cell line of human hormone-synthesizing trophoblastic cells in vitro. Cancer Res 1968;28: 1231-6.

[27] Kohler PO, Bridson WE. Isolation of hormone-producing clonal lines of human choriocarcinoma. J Clin Endocrinol 1971;32:683-7.

[28] Tso JY, Sun XH, Kao TH, Reece KS, Wu R. Isolation and characterization of rat and human glyceraldehyde-3-phosphate dehydrogenase cDNAs: genomic complexity and molecular evolution of the gene. Nucleic Acids Res 1985;13:2485-502.

[29] Pötgens AJG, Lubsen NH, Vanaltena G, Schoenmakers JGG, Ruiter DJ, Dewaal RMW. Measurement of tissue factor messenger RNA levels in human endothelial cells by a quantitative RT-PCR assay. Thromb Haemostasis 1994;71:208-13.

[30] Iochmann S, Reverdiau-Moalic P, Beaujean S, Rideau E, Lebranchu Y, Bardos P, Gruel Y. Fast detection of tissue factor and tissue factor pathway inhibitor messenger RNA in endothelial cells and monocytes by sensitive reverse transcription-polymerase chain reaction. Thromb Res 1999;94:165-73.

[31] Wun TC, Kretzmer KK, Girard TJ, Miletich JP, Broze GJ. Cloning and characterization of a cDNA coding for the lipoprotein-associated coagulation inhibitor shows that it consists of three tandem Kunitztype inhibitory domains. J Biol Chem 1988;263:6001-4.

[32] Sanger F, Nicklen S, Coulson AR. DNA sequencing with chainterminating inhibitors. Proc Natl Acad Sci USA 1977;74:5463-7.

[33] Spicer EK, Horton R, Bloem L, Bach R, Williams KR, Guha A, Kraus $\mathrm{J}$, Lin TC, Nemerson Y, Konigsberg WH. Isolation of cDNA clones coding for human tissue factor: primary structure of the protein and cDNA. Proc Natl Acad Sci USA 1987;84:5148-52.

[34] Rao CN, Gomez DE, Woodley DT, Thorgeirsson UP. Partial characterization of novel serine proteinase inhibitors from human umbilical vein endothelial cells. Arch Biochem Biophys 1995;319:55-62.
[35] Iino M, Foster DC, Kisiel W. Quantification and characterization of human endothelial cell-derived tissue factor pathway inhibitor-2. Arterioscler Thromb Vasc Biol 1998;18:40-6.

[36] Yang Y, Yelavarthi KK, Chen H, Pace JL, Terranova PF, Hunt JS. Molecular, biochemical and functional characteristics of tumor necrosis factor- $\alpha$ produced by human placental cytotrophoblastic cells. J Immunol 1993;1993:5614-24.

[37] Hohn HP, Linke M, Ugele B, Denker HW. Differentiation markers and invasiveness: discordant regulation in normal trophoblast and choriocarcinoma cells. Exp Cell Res 1998;244:249-58.

[38] Tremblay J, Hardy DB, Pereira LE, Yang K. Retinoic acid stimulates the expression of 11b-hydroxysteroid dehydrogenase type 2 in human choriocarcinoma JEG-3 cells. Biol Reprod 1999;60:541-5.

[39] Gilliland G, Perrin S, Blanchard K, Bunn HF. Analysis of cytokine mRNA and DNA: detection and quantitation by competitive polymerase chain reaction. Proc Natl Acad Sci USA 1990;87:2725-9.

[40] Gattei V, Degan M, DeIuliis A, Rossi FM, Aldinucci D, Pinto A. Competitive reverse-transcriptase PCR: a useful alternative to Northern blotting for quantitative estimation of relative abundances of specific mRNAs in precious samples. Biochem J 1997;325:565-7.

[41] Wang W, Dow E. Quantitative analysis of mRNA expression of neuron-specific growth-associated genes in rat primary neurons by competitive RT-PCR. Brain Res Protoc 1998;2:199-208.

[42] Rao CN, Peavey CL, Liu YY, Lapiere JC, Woodley DT. Partial characterization of matrix-associated serine protease inhibitors from human skin cells. J Invest Dermatol 1995;104:379-83.

[43] Rao CN, Reddy P, Liu YY, Otoole E, Reeder D, Foster DC, Kisiel W, Woodley DT. Extracellular matrix-associated serine protease inhibitors $(\mathrm{M}(\mathrm{r}) 33,000,31,000$, and 27,000) are single-gene products with differential glycosylation: cDNA cloning of the $33-\mathrm{kDa}$ inhibitor reveals its identity to tissue factor pathway inhibitor-2. Arch Biochem Biophys 1996;335:82-92.

[44] Rao CN, Cook B, Liu Y, Chilukuri K, Stack MS, Foster DC, Kisiel W, Woodley DT. HT-1080 fibrosarcoma cell matrix degradation and invasion are inhibited by the matrix-associated serine protease inhibitor TFPI-2/33 kDa MSPI. Int J Cancer 1998;76:749-56.

[45] Dvorak HF, Van de Water L, Bitzer AM, Dvorak AM, Anderson D, Harvey VS, Bach R, Davis GL, De Wolf W, Carvalho ACA. Procoagulant activity associated with plasma membrane vesicles shed by cultured tumor cells. Cancer Res 1983;43:4434-41.

[46] Murray JC. Coagulation and cancer. Br J Cancer 1991;64:422-4.

[47] Rao LVM. Tissue factor as a tumor procoagulant. Cancer Metastasis Rev 1992;11:249-66.

[48] Rao CN, Mohanam S, Puppala A, Rao JS. Regulation of ProMMP-1 and ProMMP-3 activation by tissue factor pathway inhibitor-2/matrixassociated serine protease inhibitor. Biochem Biophys Res Commun 1999;255:94-8.

[49] Izumi H, Takahashi C, Oh J, Noda M. Tissue factor pathway inhibitor2 suppresses the production of active matrix metalloproteinase- 2 and is down-regulated in cells harboring activated ras oncogenes. FEBS Lett 2000;481:31-6.

[50] Konduri SD, Tasiou A, Chandrasekar N, Rao JS. Overexpression of tissue factor pathway inhibitor-2 (TFPI-2), decreases the invasiveness of prostate cancer cells in vitro. Int J Oncol 2001;18:127-31.

[51] Rao CN, Lakka SS, Kin Y, Konduri SD, Fuller GN, Mohanam S, Rao JS. Expression of tissue factor pathway inhibitor 2 inversely correlates during the progression of human gliomas. Clin Cancer Res 2001; 7:570-6.

[52] Librach CL, Werb Z, Fitzgerald ML, Chiu K, Corwin NM, Esteves RA, Grobelny D, Galardy R, Damsky CH. 92-kD type IV collagenase mediates invasion of human cytotrophoblasts. J Cell Biol 1991;113: $437-49$.

[53] Huppertz B, Kertschanska S, Demir AY, Frank HG, Kaufmann P. Immunohistochemistry of matrix metalloproteinases (MMP), their substrates, and their inhibitors (TIMP) during trophoblast invasion in the human placenta. Cell Tissue Res 1998;291:133-48. 